Jahangirnagar University J. Biol. Sci. 7(2): 13-19, 2018 (December)

\title{
Detection of pathogenic bacteria from raw, pasteurized and UHT milk available in the local market of Gazipur District
}

\author{
Nazia Afrin", S.M. Rokon-Ud-Doula and Rasheda Yasmin Shilpi \\ Department of Botany, Jahangirnagar University, Savar, Dhaka-1342, Bangladesh
}

\begin{abstract}
The present study was undertaken with the aim of investigating the bacteriological quality of locally available raw, pasteurized and UHT milk in Gazipur District. A total 5 raw, pasteurized and UHT milk samples were collected during November to December 2016. All the pasteurized and UHT milk samples showed the total aerobic heterotrophic bacterial (TAHB) level above the standard acceptable range (i.e. $>10^{4} \mathrm{cfu} / \mathrm{ml}$ for pasteurized milk and $>0$ for UHT milk). Both Gram positive and Gram negative pathogenic bacteria viz. Staphylococcus aureus, S. epidermidis, Bacillus sp., Pseudomonas sp. and Enterobacter sp. were isolated from studied samples. API $20 \mathrm{E}$ was used for confirmation of Pseudomonas sp. This study indicates that most of the pasteurized and UHT milk samples were not satisfactory in terms of public health standard. Therefore, care must be taken to avoid possible health risk in every step involving collection, transportation, storage and post pasteurization handing of raw milk.
\end{abstract}

Key words: Pathogenic bacteria, raw milk, pasteurized milk and UHT milk.

\section{INTRODUCTION}

Milk is a complex mixture of carbohydrates, proteins, lipids, other organic compounds and inorganic salts dissolved (or) dispersed in water (Srilakshmi, 1999). It is nearly neutral in $\mathrm{pH}$ and rich in vitamins and minerals (Oftedal \& Jenness, 1988). Milk and milk products are considered as ideal foods for all age groups all over the world. However, high moisture in milk and milk products including pasteurized and refrigerated samples favor the growth and multiplication of bacterial flora. Mostly milk gets contaminated from environment through handling operation during and after milking. This bacterial flora along with yeasts and molds may significantly influence the quality of milk and milk products (Uddin et al., 2010). Milk might also be contaminated with the pathogenic bacteria or bacterial toxins which may serve as a vehicle for the transmission of diseases such as salmonellosis, diarrhea, food poisoning, tuberculosis to human (Pelczer et al., 1991).

Pasteurization temperature $\left(161.6^{\circ} \mathrm{F}\right.$ for 15 seconds $)$ can kill most heat resistant and nonspore forming pathogenic bacteria such as Mycobacterium tuberculosis and Coxiella burnetti but some species of thermoduric (Bacillus, Clostridium, Micrococcus, Mycobacterium, Lactobacillus and also sometimes Streptococcus) and gram-negative, rod-shaped bacteria can survive at this temperature (Chavarri et al., 2000; Lejeune \&

* Corresponding author. E-mail: naziaafrim49@gmail.com 
Rajala-Schultz, 2009; Chavan et al., 2011). Similarly, psychrotropic spore formers, capable of multiplying at $5^{\circ} \mathrm{C}$ or below have been isolated from refrigerated pasteurized milk (Megha \& Annandurai, 2014) which include members of the genera Achromobacter, Aerobacter Alcaligenes, Escherichia, Flavobacterium, Pseudomonas, and Vibrio (Megha \& Annadurai, 2014). Again, Aslam \& Hurley (1996) confirmed that Micrococci, Bacilli, Staphylococci, Lactobacilli, Pseudomonas and coliforms can also withstand temperature below $7^{\circ} \mathrm{C}$ and change the properties of milk. All these reported incidents are noticed in other parts of the world even from the developed countries.

In Bangladesh, the majorities of small dairy farms employ poor technology and have deficiencies in sanitation and animal sanitary control resulting in a low quality product. Besides, it is still common to find non refrigerated milk containers by the roads waiting for collection by the cooperative's truck which increases the risk of staphylococcal food poisoning. Moreover, only a few reports are available about the microbiological quality of these foods in Bangladesh, where bacterial activity could be higher due to elevated temperature and humidity. Therefore, this study was aimed to assess the microbiological quality and safety of locally produced raw milk, pasteurized milk and UHT milk available in local market.

\section{MATERIALS AND METHODS}

Sample collection: Five raw and pasteurized milk samples were collected from different local market of Gazipur City and its surrounding area. Raw milk was collected in sterile bottle and immediately transported to the laboratory. The samples were preserved at $4^{\circ} \mathrm{C}$ for detailed study.

Isolation of bacteria: Bacterial enumeration and isolation was carried out by spread plate method in Nutrient Agar media (NA) (Eklund \& Lankford, 1967) at adjusted pH 6. The microbiological condition of safety and hygiene were then assayed using the methods recommended by International Commission on Microbiological Specifications for Foods (ICMSF, 2005). Bacterial isolates were purified by repeated streaking as well as stored in NA slants at $4{ }^{\circ} \mathrm{C}$ for further analysis.

Microbial load determination: Microbial load was determined from the total number of discrete colonies counted after incubation. Isolated colonies were counted in colony formation unit as Number of cfu/volume plated dilution factor.

Identification of the isolates: The selected bacterial colonies were observed to study various characters viz. color, form, elevation, margin, surface, optical characters etc. according to Eklund \& Lankford (1967). Bacterial colonies were cultured on different selective and differential media such as: MSA, SSA, EMB, MacConkey, Bouillon agar, King's B, XLD, Simon Citrate etc. Different biochemical tests (Casein test, Fermentation test, Indole test, Starch hydrolysis test, Catalase test) were also performed. Results of the morphological, cultural and biochemical tests of selected isolates were analyzed following Bergey's Manual of Systematic Bacteriology (Sneath et al., 1986) and Bergey's 
Manual of Determinative Bacteriology (Buchanan et al., 1974). Coagulase test, endospore staining and API $20 \mathrm{E}$ (Holmes et al., 1978) were used as a confirmation test of bacterial genus or species of Staphylococcus aureus, Bacillus sp. and Pseudomonas sp.

\section{RESULTS AND DISCUSSION}

A total of 25 bacterial isolates was obtained from raw milk and processed liquid milk products. Mean heterotrophic bacterial load of the milk samples ranged from $6.25 \times 10^{3}$ to $5.5 \times 10^{4} \mathrm{cfu} / \mathrm{ml}$. In case of pasteurized milk, maximum heterotrophic bacterial count was observed in the Aarong milk (Table 1). While, in case of UHT (Ultra-high temperature processing) milk, maximum heterotrophic bacterial count was observed in the Pran UHT milk (Table 1). According to guidelines elaborated by the International Commission on Microbiological Specifications for Foods (ICMSF 2005), the total bacterial count in raw milk below $5 \times 10^{4} \mathrm{cfu} / \mathrm{ml}$ is indicative of their acceptable quality, the counts of $5 \times 10^{4}$ to $1.5 \times 10^{5} \mathrm{cfu} / \mathrm{ml}$ indicates their permissible quality, whereas bacterial count exceeding $1.5 \times 10^{5} \mathrm{cfu} / \mathrm{ml}$ is unacceptable. In pasteurized milk, the total bacterial count below $10^{4}$ $\mathrm{cfu} / \mathrm{ml}$ indicate of their acceptable quality, the counts of $10^{4}$ to $10^{5} \mathrm{cfu} / \mathrm{ml}$ represents of its permissible quality, whereas bacterial count exceeding $10^{5} \mathrm{cfu} / \mathrm{ml}$ is unacceptable. UHT products should be sterile according to guidelines of ICMSF. In view of these guidelines, CFU results showed relatively poor quality of the analyzed milk samples (Table 1). Only the raw cow milk and milk vita pasteurized milk sample showed acceptable limit of bacterial count rather than both Aarong pasteurized and UHT milk samples.

Table 1. Bacterial load of different pasteurized milk and raw milk samples

\begin{tabular}{lcc|c}
\hline Sample & Bacterial load(Mean value) & $\mathbf{m}^{*}$ & $\mathbf{M}^{*}$ \\
\hline Raw milk & $5.5 \times 10^{4}$ & $5 \times 10^{4}$ & $1.5 \times 10^{5}$ \\
Aarong pasteurized milk & $4.5 \times 10^{7}$ & & \\
Milk vita pasteurized milk & $5.7 \times 10^{4}$ & $10^{4}$ & $10^{5}$ \\
Pran UHT milk & $2.39 \times 10^{5}$ & & \\
Farm fresh UHT milk & $6.25 \times 10^{3}$ & 0 & \\
\hline
\end{tabular}

*m, acceptable level and values above it are marginally acceptable or unacceptable in the terms of the sampling plan and $\mathrm{M}$, a microbiological criterion which separates marginally acceptable quality from defective quality according to ICMSF. Bacterial load represents as $\mathrm{cfu} / \mathrm{ml}$

In the present study, Staphylococcus aureus, S. epidermidis, Bacillus sp., Pseudomonas sp. and Enterobacter sp. were presumptively isolated through their typical colony characteristics onto specific culture media. $S$. aureus gave yellow colored and $S$. epidermidis gave pink colored colony on MSA media (Plate. 1B). Bacillus sp. gave white colored colony on Bouillon agar and Pseudomonas sp. (Plate. 2G) showed greenish yellow colored colony on King's B media. Enterobacter sp. (Plate. $2 \mathrm{H}$ ) was identified by its pink colored colony on MacConkey agar media. In addition to, results of biochemical tests of different isolates revealed that out of 19 isolates 11 isolates were Gram positive while the rest were Gram negative (Plate. 1D) and rod shaped. Among the Gram-positive isolates 9 were cocci (Plate. 1C) and 2 were rod shaped. All the isolates were catalase positive (Plate. 1F), casein negative, lactose fermentation negative and indole negative. 
Out of 19 isolates only 6 isolates showed positive in starch hydrolysis test (Plate. 1E) and 2 were positive for endospore staining which indicates the presence of Bacillus sp. Among 9 cocci shaped bacteria 7 were positive for coagulase test which confirmed the presence of S. aureus. API 20 E test (Plate. 2I) confirmed the presence of Pseudomonas sp.
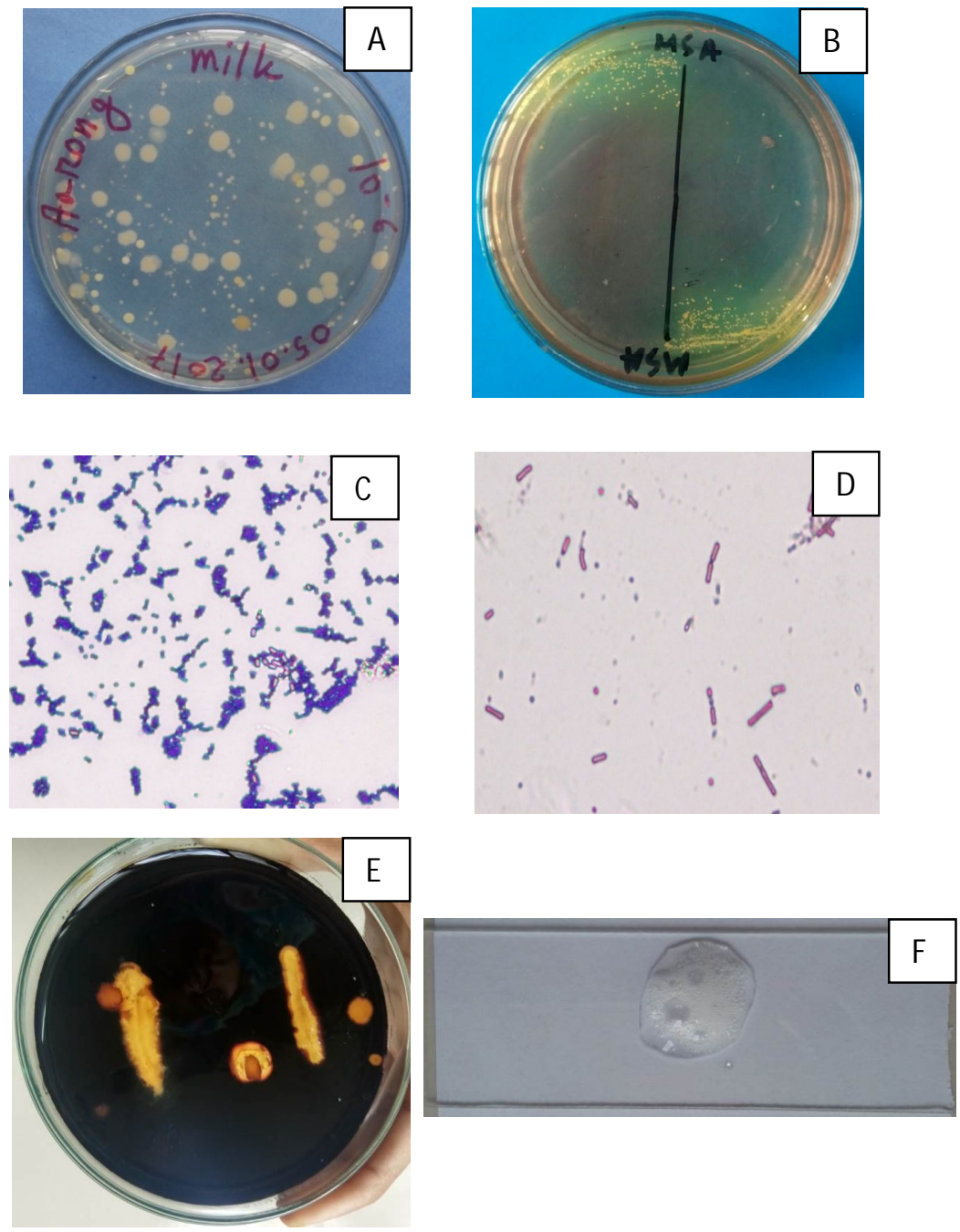

Plate 1. Bacterial isolates on Nutrient agar (A), Staphylococcus aureus (yellow colonies) on MSA media (B), gram staining represents Gram positive (cocci shaped) $S$. aureus (C) and rod shaped Gram negative Enterobacter sp. (D), starch hydrolysis test (E), catalase test $(\mathrm{F})$ 
S. aureus, B. cereus, P. aeruginosa, Proteus mirabilis, Escherichia coli, Micrococcus luteus and Serratia marcescens have been found in raw milk were reported by Megha \& Annadurai (2014). These findings are in agreement to our present study where we identified S. aureus, S. epidermidis, Bacillus sp. and Pseudomonas sp. from raw and pasteurized milk samples. These pathogens are predominantly resulting of poor handling and unclean conditions. Sources of the contaminations in raw milk are utensil, handlers, udders and teats of cow and buffalos. So, maintaining proper hygiene during milk collections from cow and buffalos and cleaning animal's teats and collection vessel with clean water can minimize the contamination.

Pasteurization of milk was aimed to destroy pathogenic microbes, prevent microbial spoilage, reduce the activity of the enzymes and increase the shelf life of products. Thus, pasteurization process improves the quality of milk. But spoilage of processed milk has still been reported (Boor \& Murphy, 2002 and Hayes \& Boor, 2001). Among microorganisms found in pasteurized milk, psychotropic bacteria are considerably the most important and common altering the quality of milk (Sorhaug \& Stepaniak, 1997). In the present study, we also identified different psychotropic bacteria from pasteurized milk. The presence of these organisms in milk indicated poor hygenic conditions. Besides these, Ruegg \& Reinemann (2002) and Schelderman et al. (2005) found a number of spores forming bacterium that is resistant to high temperatures in fresh milk. Thermoduric bacteria that can grow at temperatures of pasteurization are Bacillus, Clostridium, Micrococcus, Mycobacterium, Lactobacillus and sometimes also Streptococcus. We also identified thermoduric bacteria Bacillus sp. from our studied samples. Similar findings were also reported by Hassan et al. (2009).
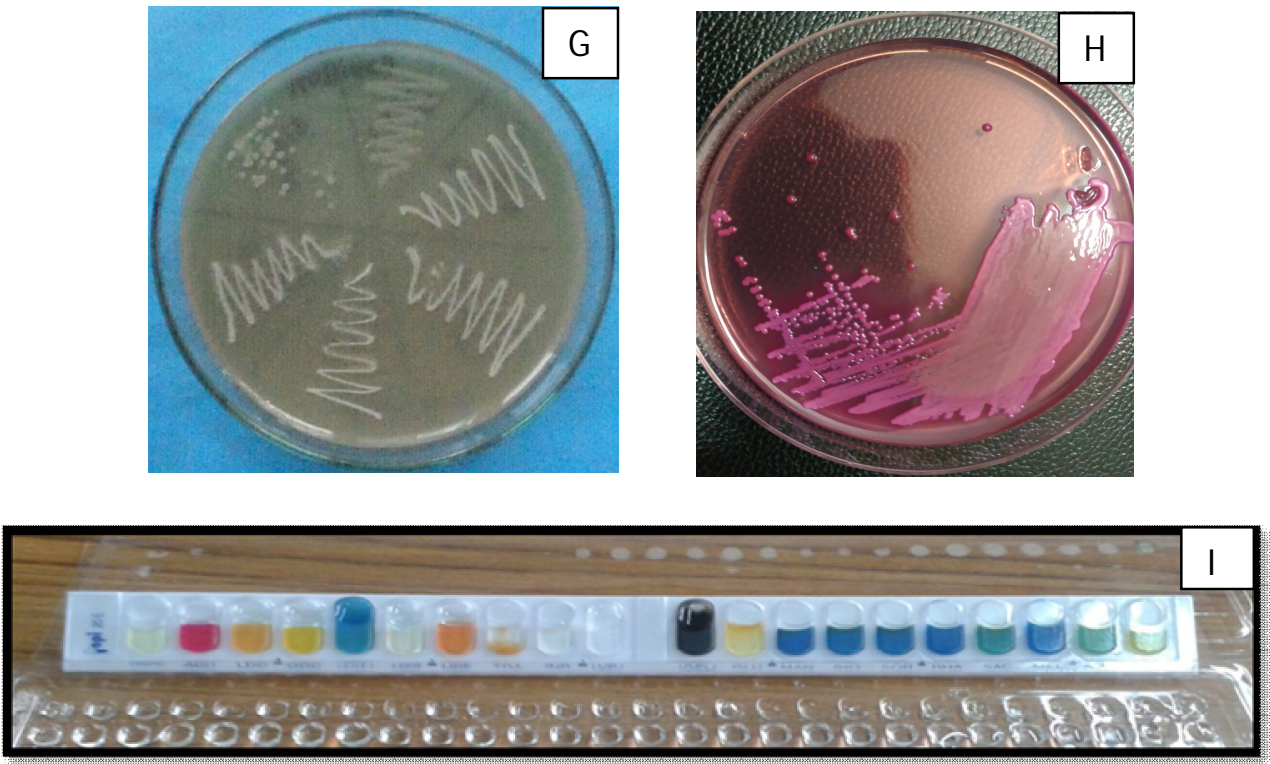

Plate 2. Bacterial isolates on King's B media (Pseudomonas sp.) G, Enterobacter sp. on MacConkey (H) and API 20 E for Pseudomonas sp. (I) 
Besides, Masiello et al. (2016) showed a considerable diversity of coliforms in liquid milk. Coliform bacteria such as: Enterobacter sp. was also isolated from our milk samples. The presence of coliform bacteria in pasteurized liquid milk typically indicates that product contamination occurred downstream of the pasteurizer, but it also indicates pasteurization failure. Milk easily favors the growth and multiplication of many bacteria, even after pasteurization or storage in refrigerator. These bacteria may significantly influence the quality of the milk and milk products. The origin of pathogenic microorganisms present in milk may be bovine or human origin and in some cases it may be transmitted by both (Seguin et al., 1999 and Khan et al., 2000).

So, from the present study, it can be concluded that the microbiological quality of most of the raw, pasteurized and UHT milk samples collected from different areas of Gazipur District were not satisfactory as some pathogenic bacteria such as Bacillus sp., Enterobacter sp., Pseudomonas sp., S. aureus and S. epidermidis were detected from the samples. The presence of $S$. aureus and Bacillus sp. will render milk unfit for human consumption, since sufficient number of these organisms may pose the risk of infection and intoxication. So, microbiological surveillance study could play an important role in the dairy industry to protect the public health and can reduce economic losses by the early detection of inadequate processing, packaging and or refrigeration.

Therefore, in order to reduce the bacterial contamination in raw, pasteurized and UHT milk, proper hygienic conditions should be followed from milking, handling and storage to the pasteurization and post pasteurization steps. Since soil, water, skin, hair of animal and air act as a source of contamination, their direct contact with milk should be avoided. Proper refrigeration temperature should be maintained.

\section{REFERENCES}

Aslam, M. and Hurley, W.L. 1996. Proteases in Milk. Illinois Dairy Report Home Page. 1-3.

Boor, K.J. and Murphy, S.C. 2002. Microbiology of market milks in dairy microbiology handbook. John Wiley and Sons, Inc., New York, pp.91-122.

Buchanan, R.E. and Gibbons, N.E. 1974. Bergey's Manual of Determinative Bacteriology (8 ed.). The Williams and Wilkins Company. USA. pp: 1268.

Chavan, R.S., Chavan, S.R., Khedkar, C.D. and Jana, A.H. 2011. UHT milk processing and effect of plasmin activity on shelf life: A Review. Comprehensive Reviews in Food Science and Food Safety. 10:251-268.

Chavarri, F., Bustamante, M.A., Santisteban, A., Virto, M., Albisu, M., Barron, L.J.R. and deRenobales, M. 2000. Effect of milk pasteurization on lipolysis during ripening of ovine cheese manufactured at different times of the year. Lait. 80:433-444.

Eklund, C. and Lankford, C.E. 1967. Laboratory manual for general microbiology. Prentice-Hall International Inc. London. pp. 299.

Hassan, N.B.A., Abdalla, M.O.M. and Nour, A.A.A.M. 2009. Microbial quality of heat-treated milk during storage. Pakistan Journal of Nutrition. 8(12):1845-1848.

Hayes, M.C., Ralyeas, R.D., Murphy, S.C., Carey, N.R., Scarlett, J.M. and Boor, K.J.I. 2001. Identification and characterization of elevated microbial counts in bulk tank raw milk. J. Dairy Sci., 84: 292-298. 
Pathogenic bacteria, raw, pasteurized and UHT milk, local market, Gazipur

Holmes, B., Willcox, W.R. and Lapage, S.P. 1978. Identification of Enterobacteriaceae by the API 20E system. Journal of Clinical Pathology. 31:22-30.

ICMSF, 2005. Spices, herbs, and vegetable seasonings. In: ICMSF (International Commission on Microbiological Specifications for Foods) (Ed.), Microorganisms in Foods, Microbial Ecology of Food Commodities. Kluwer Academic/Plenum Publishers, London. pp. 360372.

Khan, S.A., Nawaz, M.S., Khan, A.A. and Cerniglia, C.E. 2000.Transfer of erythromycin resistance from poultry to human clinical strains of Staphylococcus aureus. J. Clin. Microbiol. 38: 1832-1838.

Lejeune, J.T. and Rajala-Schultz, P.J. 2009. Unpasteurized milk: A continued public health threat. Oxford Journals. Medecine. Clinical Infectious Diseases. 48(1):93-100.

Masiello, S.N., Martin N.H., Trmčić, A., Wiedmann, M. and Boor, K.J. 2016.Identification and characterization of psychrotolerant coliform bacteria isolated from pasteurized fluid milk. Journal of Dairy Science. 99 (1):130-140.

Megha, S.V. and Annadurai, B. 2014. Isolation and identification of proteolytic bacteria from raw milk samples. Global Journal of Bio-Science and Biotechnology. 3 (4): 391- 397.

Oftedal, O.T. and Jenness, R. 1988. Interspecies variation in milk composition among horses, zebras and asses (Perissodactyla:Equidae). Journal of Dairy Research. 55:57- 66.

Pelczar, M.J.J.R. and Reid, R.D. 1991. Microbiology, $5^{\text {th }}$ ed. Tata Mcgraw Hill Publishing Company Ltd. New York.

Ruegg, P.L. and Reinemann, D.J. 2002. Milk quality and mastitis test. University of Wisconsin Extension Services. The Bovine Prac. 36:1-13.

Scheldeman, P., Pil, A., Herman, L., De Vos, P. and Heyndrickx, M. 2005. Incidence and diversity of potentially highly heat-resistant spores isolated at dairy farms. Applied and Environmental Microbiology. 71:1480-1494.

Seguin, J.C., Walker, R.D., Caron, J.P., Kloos, W.E., George, C.G., Hollis, R.J., Jones, R.N. and Pfaller, M.A. 1999. .Methicillin-resistant Staphylococcus aureus outbreak in a veterinary teaching hospital: potential human-to animal transmission. J. Clin. Microbiol., 37(5): 1459-1463.

Sneath, P.H.A., Mair, N.S., Sharpe, M.E., Holt, J.G., Frank, C., Prager, R., Rabsch, W. and Feil, F.B.S. 1986. Bergey's manual of systematic bacteriology $\left(9^{\text {th }}\right.$ ed. $)$, vol. 2. Williams and Wilkins. Baltimore, London. pp: 1599.

Sorhaug, T. and Stepaniak, L. 1997. Psychrotrophs and their enzymes in milk and dairy products: Quality aspects. Trends in Food Science \& Tech. 8: 35-41

Srilakshmi, B. 1999. Food Science. New age International private limited publishers, Delhi. pp. 521.

Talaro, K.P. 2005. Foundations in Microbiology 5th ed. New York: McGraw-hill Higher Education, pp. 815-817.

Uddin, M.A., Haque, H.M.M-U. and Noor, R. 2011. Isolation and Identification of Pathogenic Escherichia coli, Klebsiella spp. and Staphylococcus spp. in Raw Milk Samples Collected from Different Areas of Dhaka City, Bangladesh. Stamford Journal of Microbiology. 1(1):19-23. 